Article

\title{
Impact of Potentially Contaminated River Water on Agricultural Irrigated Soils in an Equatorial Climate
}

\author{
Juan M. Trujillo-González ${ }^{1}$ (D), Juan D. Mahecha-Pulido ${ }^{1}$, Marco A. Torres-Mora ${ }^{1}$, \\ Eric C. Brevik ${ }^{2}$, Saskia D. Keesstra ${ }^{3}$ and Raimundo Jiménez-Ballesta ${ }^{4, *}$ \\ 1 Instituto de Ciencias Ambientales de la Orinoquia Colombiana ICAOC, Facultad de Ciencias \\ Básicas e Ingeniería, Universidad de los Llanos, Campus Barcelona Villavicencio, 500001 Villavicencio, \\ Colombia; jtrujillo@unillanos.edu.co (J.M.T.-G.); juandmahechap@gmail.com (J.D.M.-P.); \\ mtorres38@gmail.com (M.A.T.-M.) \\ 2 Department of Natural Sciences, Dickinson State University, Dickinson, ND 58601, USA; \\ eric.brevik@dickinsonstate.edu \\ 3 Soil Physics and Land Management Group, Wageningen University, Droevendaalsesteeg 4, \\ 6708PB Wageningen, The Netherlands; saskia.keesstra@wur.nl \\ 4 Department of Geology and Geochemistry, Universidad Autónoma, 28049 Madrid, Spain \\ * Correspondence: raimundo.jimenez@uam.es; Tel.: +34-914-974-810
}

Academic Editors: Rabin Bhattarai and Paul Davidson

Received: 6 April 2017; Accepted: 21 June 2017; Published: 24 June 2017

\begin{abstract}
Globally, it is estimated that 20 million hectares of arable land are irrigated with water that contains residual contributions from domestic liquids. This potentially poses risks to public health and ecosystems, especially due to heavy metals, which are considered dangerous because of their potential toxicity and persistence in the environment. The Villavicencio region (Colombia) is an equatorial area where rainfall (near $3000 \mathrm{~mm}$ /year) and temperature (average $25.6^{\circ} \mathrm{C}$ ) are high. Soil processes in tropical conditions are fast and react quickly to changing conditions. Soil properties from agricultural fields irrigated with river water polluted by a variety of sources were analysed and compared to non-irrigated control soils. In this study, no physico-chemical alterations were found that gave evidence of a change due to the constant use of river water that contained wastes. This fact may be associated with the climatic factors (temperature and precipitation), which contribute to fast degradation of organic matter and nutrient and contaminants (such as heavy metals) leaching, or to dilution of wastes by the river.
\end{abstract}

Keywords: trace elements; equatorial area; agricultural land use; wastewater irrigation

\section{Introduction}

The role of equatorial regions of the world in global food production is increasing [1]. Management of resources to produce more food in a sustainable manner has become increasingly important $[2,3]$. Anthropogenic contamination of soils by sewage and industrial chemicals has become a major source of concern. The input of toxic levels of trace elements into soils has occurred as a result of the use of agricultural chemicals [4] and sewage water for irrigation [5,6]. The productive use of wastewater has increased, as millions of small-scale farmers in urban and peri-urban areas of developing countries depend on wastewater or water sources, such as rivers, contaminated with wastewater to irrigate high-value edible crops for urban markets, often because they have no alternative sources of irrigation water. Undesirable constituents in wastewater can harm human health and the environment $[7,8]$. Proper use of wastewater with appropriate pretreatments can improve soil health without risking human health, but those pretreatments do not happen in many instances $[9,10]$. 
The dumping of domestic and industrial municipal wastewater dates back 400 years and is now a common practice in many parts of the world [11]. It is estimated that 20 million hectares of arable land globally are irrigated with water with residual contributions from domestic liquids without treatment or with inadequate treatment [12-14]. This poses risks to public health and ecosystems, especially due to the content of heavy metals, considered dangerous because of their potential toxicity and persistence in the environment [15-17]. Also, the ability to reduce fertilizer inputs due to the nutrient content of wastewater motivates farmers to use these waters to irrigate crops, and the application to cropland is often seen as being an environmentally acceptable disposal method for effluents $[13,14,18]$. Positive effects on soil biodiversity following wastewater application have also been reported [19].

Heavy metals and trace elements in the soil system are issues that are of specific interest as they fall into two categories [20,21]. Metals such as copper $(\mathrm{Cu})$, zinc $(\mathrm{Zn})$, manganese $(\mathrm{Mn})$, iron (Fe), and molybdenum (Mo) have been identified as essential micronutrients for plant growth, while cadmium $(\mathrm{Cd})$, lead $(\mathrm{Pb})$, chromium $\left(\mathrm{Cr}^{6+}\right)$, nickel $(\mathrm{Ni})$, mercury $(\mathrm{Hg})$ and arsenic $(\mathrm{As})$, besides not being essential to plants, have toxic effects even at very low concentrations [22,23]. The accumulation of heavy metals in agricultural soils can affect the food chain by being transferred from soil to plant to humans, with the potential to negatively affect human health [24]. The levels of heavy metals in soils vary between regions and depend on factors including the parent material, application of fertilizers containing traces of these elements $[5,25]$, and other factors such topography. The concentrations of heavy metals in wastewater are low, but prolonged use increases the possibility of accumulation of contamination in soil and groundwater, and transfer of those pollutants to plants [26,27]. Wastewater may contain residues of industrial or domestic origin as well as urban runoff [16,28]. Guénon et al. [29] reported that, in untreated wastewater, concentrations of $\mathrm{Pb}$ and methylmercury can reach $0.16 \pm 0.05 \mathrm{mg} / \mathrm{L}$ and $3.8 \pm 2.5 \mathrm{ng} / \mathrm{L}$, respectively. Recently, technologies such as biochar have been proposed to phytostabilize contaminants in the soil and could potentially sequester contaminates and convert soils degraded by contamination into productive ecosystems once again [30-32].

In this regard, the continued use of wastewater potentially threatens soil resources traditionally used to support food production [33], as well as many other human activities. Soil is a dynamic entity serving five major biophysical functions: nutrient cycling; water retention; biodiversity and habitat; storage, filtering, buffering and transformation of compounds; and physical stability and support [34], all essential for the development of societies and for the determination of environmental quality functions [35,36]. However, due to population growth, especially in developing counties, demand for goods and services has increased, and inadequate farming practices became factors that drove soil degradation and declines in soil $C$ and nutrient concentrations [36-38]. To counteract the negative effect of land degradation due to pollution in peri-urban irrigated agricultural areas, monitoring programs need to be stablished for agricultural practices in peri-urban areas that use water contaminated from domestic and industrial waste for irrigation to assess the impact of the contaminated water use on the functioning of soil. In addition, there is a need to develop measures to promote soil conservation and/or remediation, especially in developing regions, where there is a lack of treatment systems for domestic wastewater and storm water, and where industrial activity is high [39].

Although studies have been published on the use of contaminated water in agriculture in developing countries such as India and Zimbabwe [15,40-42], there is little published data from Latin American developing countries. There is also little data for equatorial areas where rainfall exceeds $3000 \mathrm{~mm} /$ year, even though these areas are important for food production. One example of such an agricultural area is the region around the city of Villavicencio in Colombia.

A systematic study was conducted on the effect of river water contaminated by a variety of sources on soil pollution levels in the Villavicencio equatorial region. In this study, the impact of the use of contaminated river water for irrigation on the levels of trace elements in the soils in the area was assessed. The objectives of the present study were: (1) to identify the different sources of pollutants in the Ocoa river, the main water source running through the urban area of the city of Villavicencio; and (2) analyze the physico-chemical properties of agricultural soils irrigated with 
potentially contaminated water to create an effective scientific tool that assists decision makers in their attempts to preserve public health and conserve natural resources.

\section{Materials and Methods}

\subsection{Study Area}

The study site is in the Villavicencio region $\left(4^{\circ} 7^{\prime} 30^{\prime \prime} \mathrm{N}, 73^{\circ} 16^{\prime} 30^{\prime \prime} \mathrm{W}\right)$, located in the east center portion of Colombia (Figure 1). The area is characterized by high average annual rainfall $(2888.8 \mathrm{~mm}$; weather Station La Libertad-Code 35025020-IDEAM) with an average annual temperature of $25.7^{\circ} \mathrm{C}$ and plain topography at an elevation of $243 \mathrm{~m}$. This study was conducted in agricultural land irrigated with water from the Ocoa River, which includes effluents from different sources. Irrigation was applied during months that had a low supply of rainwater. Rainfall in the region is largely determined by the intertropical convergence zone, with a single mode regime where the months of April, May, June, July and October have the highest rainfall with values ranging from 305.8 to $431.6 \mathrm{~mm} / \mathrm{month}$ and the dry season occurs in the months of December, January, February and March with rainfall ranging between 25.1 and $147 \mathrm{~mm} / \mathrm{month}$; the climatic classification of the region corresponds to tropical rainforest [43]. Soils in the study area are dominated by Inceptisols and Oxisols according to Soil Taxonomy (2006). These often translate into Cambisols or Ferralsols in the system of the FAO-ISRIC-ISSS [33].

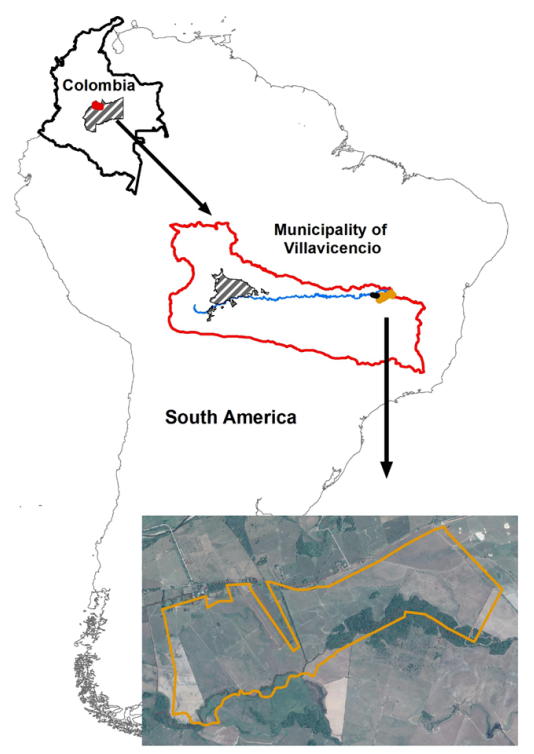

Figure 1. Geographical location of the study area. The red area in the Colombia map shows the Municipality of Villavicencio within the department of Meta (stripped pattern), the red outlined area in the middle map shows the municipality with urbanized areas in a stripped pattern and the study area in yellow, and the lower aerial photograph shows the studied fields in detail.

The primary crop at the study site was rice (Oryza sativa) with occasional maize (Zea mays) for at least 25 years prior to 2014. A flood irrigation system was used with channels that allowed irrigation water to enter the field at the rate of $150 \mathrm{~L} \mathrm{~min}^{-1}$. In 2014, most of the study site (total of $540 \mathrm{ha}$ ) was converted to pastures for cattle grazing (420 ha), with only a small amount of rice production (120 ha) on the remaining area. The irrigation channels were still maintained and irrigation applied as needed. Soil samples for this study were collected in 2015. 


\subsection{Sources of Pollutants in the River Water}

The identification of sources of pollution into the Ocoa River was done in several ways, including: field trips to find areas of effluent release, interviews with residents, photographic records, and geo-referencing (using a Global Positioning System -GPS Garmin 62SC). Points where numerous releases into the river were found were referred to as common outlet zones.

\subsection{Soil Sampling}

A total of 21 samples of agricultural land irrigated with contaminated water and 4 reference samples, or controls, in non-irrigated fields were taken in the agricultural area of interest at a depth of $0-30 \mathrm{~cm}$ [44]. There are no crops in the area irrigated with freshwater (water that does not receive contamination inputs); therefore, it was not possible to establish a control that received irrigation with non-contaminated water. Sampling was done in a systematic cross, i.e., each of the sampling points were at uniform distances from each other, covering the entire area. Each sample consisted of five sub-samples and the sampling points were located using a GPS (Garmin 62 SC) and put into ArcGis 10.1 software (Esri, Redlands, CA, USA).

\subsection{Laboratory Analysis}

The determination of the total concentrations of heavy metals in soil $(\mathrm{Cu}, \mathrm{Zn}, \mathrm{Ni}, \mathrm{Pb}, \mathrm{Cd})$ was performed by digestion in nitric acid, hydrochloric acid and hydrogen peroxide and atomic absorption spectrophotometry flame (Air-Acetylene, Environmental Protection Agency -EPA 3050B, 3111B SM). The $\mathrm{pH}$ was measured with a potentiometer in a 1:1 soil:water mix; the organic matter (OM) was determined by the Walkley-Black method [45]; available phosphorus by Bray II [45]; exchangeable bases ( $\mathrm{Ca}, \mathrm{Mg}, \mathrm{Na}, \mathrm{K}$ ) by extraction with ethyl ammonium normal ( $\mathrm{pH}$ 7.0) [45]; Ca and Mg were quantified by atomic absorption [45]; $\mathrm{Na}$ and $\mathrm{K}$ by atomic absorption spectrophotometry [45], and textural analysis by sieve and hydrometer [45]. For quality control, blank samples were analyzed after every ten samples. All chemicals and solutions were of analytical standard book-reagent grade. Lastly, the quality was assured by using duplicates.

\subsection{Statistical Methods and Isoline Plotting}

Data were analyzed with descriptive statistics including mean (Me), standard deviation (SD), and coefficient of variation (CV) and also underwent a two-tailed Student $t$-test $(p=0.05)$ for mean differences. The spatial distribution of metals was represented by Kriging interpolation using ArcGIS software version 10.1 .

\section{Results and Discussion}

\subsection{Sources of Pollutants in the River Water}

Fifty-four points were identified along the Ocoa River over a distance of $69 \mathrm{~km}$ where domestic, agricultural and industrial wastes were dumped (Figure 2). Only $15(28 \%)$ of these were authorized for dumping liquid waste, while for the remaining $39(72 \%)$ it was not possible to establish that they had authorization from the environmental authority. However, in neither of the two scenarios was treatment for the remediation of wastewater done, which illustrates the problem mentioned by UN Water [46], which states that developing countries do not treat about $90 \%$ of their liquid wastes. It was also found that $79 \%$ of the discharge points along the Ocoa River corresponded to domestic sources that were "common areas of domestic dumping" of numerous effluents. This is a common problem in all developing countries where the main problem of water pollution is due to the lack of basic sanitation, and is related to vulnerable sectors of the population that have no options other than polluted rivers as a source for the water they need to conduct essential life functions such as food preparation, personal hygiene, laundry, recreation and sewage services $[7,47]$. In the municipality of 
Villavicencio Colombia, domestic sewage (79\% of discharge sites) is concentrated and taken to points of discharge without treatment; however, not all homes are connected to the sewer system, because they have septic systems or simply pour wastes directly into a river. It was found that $17 \%$ of discharge points into the Ocoa River consisted of domestic effluent that was mixed with urban runoff, including agribusiness and car wash effluent. Industrial activity leading to hydrocarbon production accounted for $2 \%$ of the sources of pollution, and according to Ecopetrol [48], organic and inorganic compounds in the wastewater discharged to the Ocoa River remain below levels stipulated by Colombian environmental standards. The last contribution found ( $2 \%)$ was related to a closed municipal landfill, which according to authors like Krook et al. [49] and Abu-Daabes et al. [50], generated atmospheric emissions and leachates containing organic and inorganic components including heavy metals.

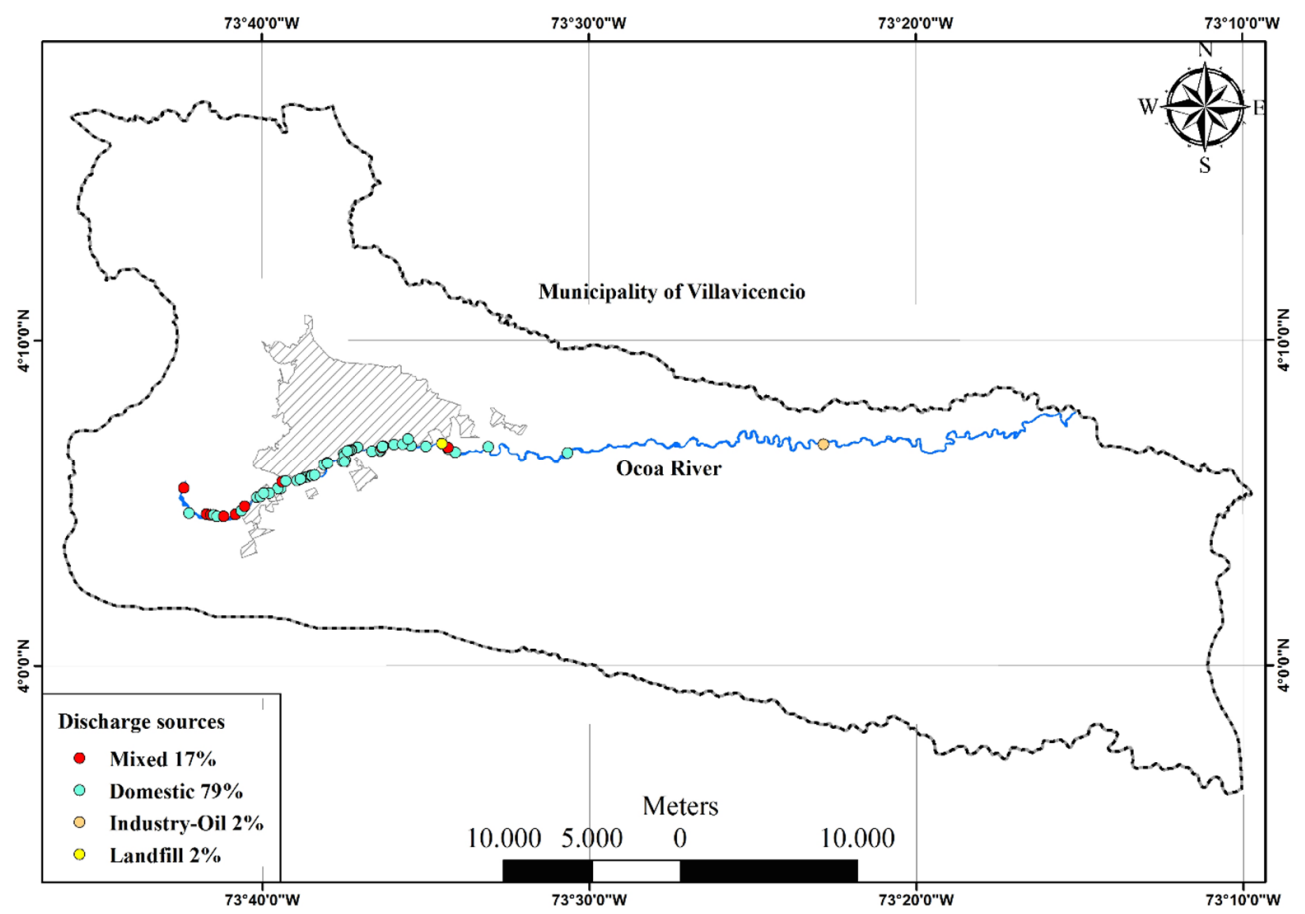

Figure 2. Distribution and sources of discharges in the Ocoa River. The stripped pattern shows urban areas.

Industrial wastewater often contains high levels of metals, non-metals, and volatile compounds, among other inorganic contaminants [51]. In general, in developing countries, government entities responsible for managing the proper use of natural resources lack the tools that would allow them to determine the load capacity of their rivers and thus apply proper management protocols for wastewater treatment and set rules for the concentrations and amounts of effluent that are allowed to be discharged into the riverine system $[17,52]$.

Based on the above, the water of the Ocoa River in the city of Villavicencio contains organic and inorganic chemicals from the direct discharges of domestic wastewater, water from mixed sources and industrial sources. This polluted water could potentially affect the health of human communities, the riverine ecosystems and alter the properties of agricultural soils that receive prolonged irrigation from wastewater sources [53].

\subsection{Physicochemical Conditions}

Soils in the study area had sand, silt and clay contents that ranged from $20.4 \%$ to $42.7 \% ; 25.6 \%$ to $43.6 \%$ and $23.4 \%$ to $41.7 \%$, respectively, with a mean \pm standard deviation of $33.23 \pm 5.8 \%$; $33.6 \pm 4.9 \%$ and $33.17 \pm 4.6 \%$, respectively. The textural class of the soils in the study area 
predominantly consisted of clay loam [54]. This coincides with the General study of soils and Zoning of Lands, Department of Meta [43], which describes the soils of the study area as Typic Tropofluvents. These soils have a medium-to-fine texture, with periodic aeration deficits as demonstrated by the presence of gray and brown mottles showing moderate-to-poor drainage, they are susceptible to flooding and are deep to very shallow, strongly acidic and have low fertility $[55,56]$.

\subsection{Chemical Analysis}

According to the statistical analysis (Table 1), the chemical conditions in the study area and the reference samples showed no significant differences with a 0.95 confidence interval (CI). The organic matter $(\mathrm{OM})$ content averaged $1.45 \%$ with a range of $1 \%$ to $2 \%$. Organic matter is important in soil because it plays a key role in the formation of aggregates, acidity control, cycling of metallic elements and detoxification of pesticides in soils [57]. In this case, the OM content was very low. The $\mathrm{pH}$ ranged from 4 to 5.1 with a mean value of 4.52 , classifying the soil as very strongly acidic according to Soil Survey Staff [58]. $\mathrm{Al}^{3+}$ averaged $1.15 \mathrm{meq} / 100 \mathrm{~g}$ soil and exchangeable bases averaged $1.22 \mathrm{meq} / 100 \mathrm{~g}$ for $\mathrm{Ca}^{2+}, 0.26 \mathrm{meq} / 100 \mathrm{~g}$ for $\mathrm{Mg}^{2+}, 016 \mathrm{meq} / 100 \mathrm{~g}$ for $\mathrm{K}^{+}$, and $0.08 \mathrm{meq} / 100 \mathrm{~g}$ for $\mathrm{Na}^{+}$. The exchangeable phosphorus averaged $8.45 \mathrm{ppm}$, ranging between 0.8 and 32.5 and showing high heterogeneity with a coefficient of variation of $103.6 \%$. Most of the metals that were tested $(\mathrm{Cu}, \mathrm{Zn}$, $\mathrm{Ni}, \mathrm{Pb}, \mathrm{Cd}$ ) were below the detection limits of the equipment used in this study.

Table 1. Descriptive statistics and Student $t$-test mean difference analysis of the area of interest and the reference area for organic matter $(\mathrm{OM}, \%)$, available phosphorus ( $\mathrm{P}, \mathrm{ppm}), \mathrm{pH}$, aluminum (Al, meq/100 g soil), and the exchangeable bases calcium (Ca), magnesium (Mg), potassium (K), and sodium $(\mathrm{Na}) \mathrm{meq} / 100 \mathrm{~g}$ soil.

\begin{tabular}{|c|c|c|c|c|c|c|c|c|c|}
\hline & & OM & $\mathbf{P}$ & $\mathrm{pH}$ & Al & $\mathrm{Ca}$ & $\mathrm{Mg}$ & $\mathbf{K}$ & $\mathrm{Na}$ \\
\hline \multirow{6}{*}{$\begin{array}{l}\text { Area of } \\
\text { interest in } \\
\text { this study }\end{array}$} & Mean & $1.5^{\mathrm{NS}}$ & $8.5^{\mathrm{NS}}$ & $4.5^{\mathrm{NS}}$ & $1.1^{\mathrm{NS}}$ & $1.2^{\mathrm{NS}}$ & $0.3^{\mathrm{NS}}$ & $0.2^{\mathrm{NS}}$ & $0.1^{\mathrm{NS}}$ \\
\hline & Minimum & 1 & 0.8 & 4 & 0.5 & 0.2 & 0.01 & 0.07 & 0.04 \\
\hline & Maximum & 2 & 32.5 & 5.1 & 2.6 & 2.2 & 0.6 & 0.4 & 0.1 \\
\hline & $\begin{array}{l}\text { Standard } \\
\text { deviation }\end{array}$ & 0.3 & 8.76 & 0.28 & 0.57 & 0.52 & 0.17 & 0.07 & 0.03 \\
\hline & $\begin{array}{l}\text { Coefficient of } \\
\text { variation \% }\end{array}$ & 19.4 & 103.6 & 6.2 & 49.7 & 42.2 & 68.4 & 44.1 & 34.1 \\
\hline & $\begin{array}{c}\text { Number of } \\
\text { measurements }\end{array}$ & 21 & 21 & 21 & 21 & 21 & 21 & 21 & 21 \\
\hline \multirow{2}{*}{$\begin{array}{l}\text { Reference } \\
\text { area }\end{array}$} & Mean & $1.4^{\mathrm{NS}}$ & $2.5^{\mathrm{NS}}$ & $3.9^{\mathrm{NS}}$ & $1.2^{\mathrm{Ns}}$ & $0.3^{\mathrm{NS}}$ & $0.2^{\mathrm{NS}}$ & $0.1^{\mathrm{NS}}$ & $\begin{array}{l}0.06 \\
\text { NS }\end{array}$ \\
\hline & $\begin{array}{c}\text { Number of } \\
\text { measurements }\end{array}$ & 4 & 4 & 4 & 4 & 4 & 4 & 4 & 4 \\
\hline \multicolumn{2}{|c|}{ Student $t$-test } & 0.998 & 0.999 & 0.999 & 0.999 & 0.998 & 0.999 & 0.999 & 0.998 \\
\hline
\end{tabular}

The use of wastewater can improve the nutritional content of agricultural soils, which is why wastewaters are used in many countries as an alternative to organic manures, generating a decrease in production costs $[29,59]$. The highest phosphorus contents were found in the area where recent agricultural activities had been conducted, while low phosphorus content existed on land that had not been in agricultural use over the past year (Figure 3). This was consistent with Sommer [60], who argued that soil heterogeneity is related to differences in parent material, climate, topography and management practices. Sinegani et al. [61] also state that the variability of surface soil in agricultural areas is primarily due to agricultural practices, while the variation in subsoil horizons is governed by pedogenic processes. In this case, phosphorus is added with agricultural activities such as irrigation 
or fertilization, while in uncultivated areas phosphorus is rapidly leached [62]. Of the heavy metals considered in this study, only $\mathrm{Zn}$ was present at detectable levels with a mean of $65.3 \mathrm{mg} / \mathrm{kg}$, while $\mathrm{Cu}$, $\mathrm{Ni}, \mathrm{Cd}$ and $\mathrm{Pb}$ did not reach the limits of quantification: $4.44,1.3,3.73$ and $6.58 \mathrm{mg} / \mathrm{kg}$, respectively, in the samples studied. These limits are below the values of phytotoxicity of these metals [63]. According to reports by Mapanda et al. [15], Alobaidy et al. [16] and Klay et al. [64], these soils were likely to have high concentrations of heavy metals, because irrigation water mixed with domestic and industrial wastewater discharges had been used on these soils for a long time ( $>25$ years). However, in our study we did not find such high concentrations due to the irrigation practices. In general, chemical conditions determined in the study area were similar to those determined by Rincón and Caicedo [65], Jamioy-Orozco et al. [66], and Mahecha-Pulido et al. [67] in nearby areas where wastewaters are not applied, and are considered typical for soils of the "Piedemonte llanero" of Colombia.

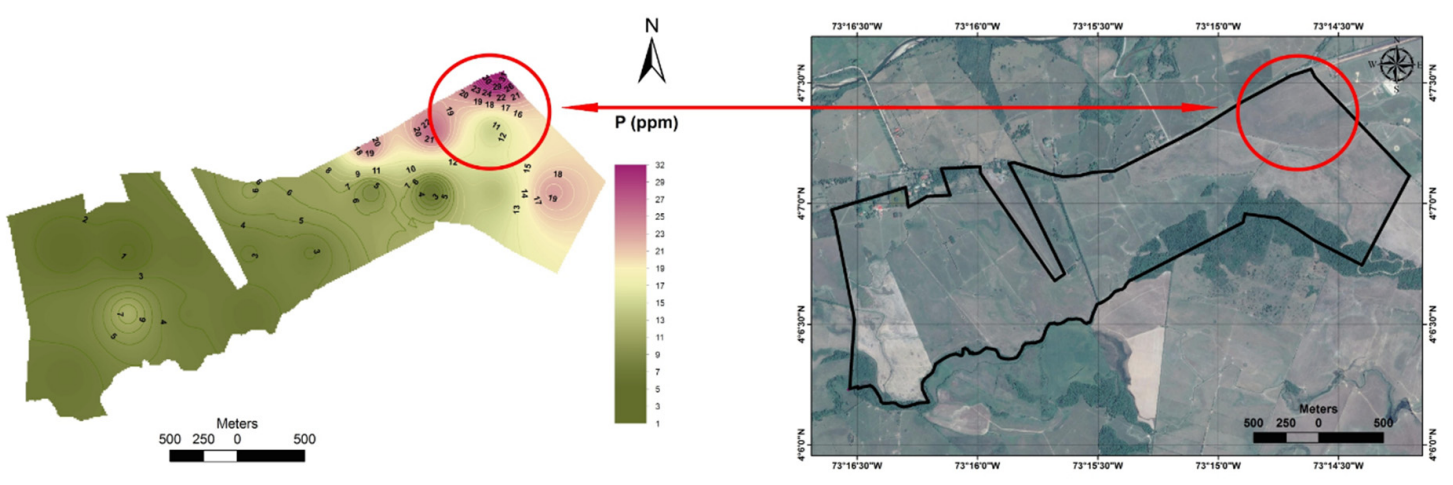

Figure 3. Distribution of phosphorus $(\mathrm{P})$ in in the $0-30 \mathrm{~cm}$ depth interval (left), satellite image of the study area from Google Earth (right).

Our data show that although these soils have textures that are often associated with nutrient-rich soils, and while they have been irrigated with water that is likely high in organic load, these soils had low nutrient content and have no problems related to heavy metals accumulation in the 0-30 cm depth interval. This may be explained by considering the climatic conditions of the sampling area (abundant rainfall and high temperatures) because different amounts of rain and varying temperatures modify how geomorphological and soil physical and hydrological processes work [68]. Yang et al. [69] and Azouzi et al. [70] suggest that in regions with such high temperatures and rainfall throughout the year, rapid oxidation of organic matter occurs and fast leaching of nutrients and pollutants such as heavy metals is common. Since climate is one of the most important factors determining soil development, vegetation cover, soil type, flora and fauna, processes in the soil such as soil degradation, erosion and loss of nutrients are also related to this [71-73]. Therefore, the most likely explanation for the low nutrient and metal contents is the very rapid processes in the soil due to the intensive climate. It is also possible that the pollutant load in the river was diluted by the river water to the point that the application of the river water as an irrigation source did not significantly impact soil properties. Either of these could explain why the mean differences between the irrigated area and the reference area were not significant.

\section{Conclusions}

Although water exposed to wastewater sources was used for irrigation in the study area, the 0-30 cm interval of soils in the Villavicencio region in Colombia showed no physico-chemical alterations that gave evidence of a change due to the constant use of contaminated irrigation water over a $25+$ year period. In addition, the behavior of phosphorus demonstrated that recent agricultural activities are important factors when evaluating the physicochemical conditions of these soils. Finally, it is necessary to establish reference values for this region and monitoring strategies to assess any geochemical changes, especially in soils irrigated with effluent-laden waters from various sources. 
Acknowledgments: The authors wish to acknowledge the financial support given by Ecopetrol SA, by the alliance with Universidad de los Llanos, 5211592, "Proyecto Cuencas", to the staff of the Instituto de Ciencias Ambientales de la Orinoquia Colombiana-ICAOC (Universidad de los Llanos), and to the Fondo Social de la Educación Superior de la Gobernación del Meta.

Author Contributions: This work was carried out in collaboration between all authors. Trujillo and Jiménez designed the study, wrote the protocol, and wrote the first draft of the manuscript. Brevik and Keeesstra managed the literature searches and contributed to analyses of data, and Mahecha and AM Torres managed the experimental process. All authors read, contributed to, and approved the final manuscript.

Conflicts of Interest: There is not conflict of interest.

\section{References}

1. Buol, S.W. Soils and agriculture in central-west and north Brazil. Sci. Agric. 2009, 66, 697-707. [CrossRef]

2. Brevik, E.C.; Calzolari, C.; Miller, B.A.; Pereira, P.; Kabala, C.; Baumgarten, A.; Jordán, A. Soil mapping, classification, and pedologic modeling: History and future directions. Geoderma 2016, 264, $256-274$. [CrossRef]

3. Keesstra, S.D.; Johan, B.; Jakob, W.; Pablo, T.; Pete, S.; Artem, C.; Luca, M.; John, Q.; Yakov, P.; Wim, H.; et al. The significance of soils and soil science towards realization of the United Nations Sustainable Development Goals. Soil 2016, 2, 111-128. [CrossRef]

4. Czarnecki, S.; Düring, R.A. Influence of long-term mineral fertilization on metal contents and properties of soil samples taken from different locations in Hesse. Ger. Soil 2015, 1, 23-33. [CrossRef]

5. Singh, A.; Sharma, R.K.; Agrawal, M.; Marshall, F.M. Risk assessment of heavy metal toxicity through contaminated vegetables from waste water irrigated area of Varanasi, India. Trop. Ecol. 2010, 51, 375-387.

6. Vergine, P.; Lonigro, A.; Salerno, C.; Rubino, P.; Berardi, G.; Pollice, A. Nutrient recovery and crop yield enhancement in irrigation with reclaimed wastewater: A case study. Urban Water J. 2017, 14, 325-330. [CrossRef]

7. Qadir, M.; Wichelns, D.; Raschid-Sally, L.; McCornick, P.G.; Drechsel, P.; Bahri, A.; Minhas, P.S. The challenges of wastewater irrigation in developing countries. Agric. Water Manag. 2010, 97, 561-568. [CrossRef]

8. Helmke, M.F.; Losco, R.L. Soil's Influence on Water Quality and Human Health. In Soils and Human Health; Brevik, E.C., Burgess, L.C., Eds.; CRC Press: Boca Raton, FL, USA, 2012; pp. 155-176.

9. Becerra-Castro, C.; Lopes, A.R.; Vaz-Moreira, I.; Silva, E.F.; Manaia, C.M.; Nunes, O.C. Wastewater reuse in irrigation: A microbiological perspective on implications in soil fertility and human and environmental health. Environ. Int. 2015, 75, 117-135. [CrossRef] [PubMed]

10. Gatta, G.; Libutti, A.; Beneduce, L.; Gagliardi, A.; Disciglio, G.; Lonigro, A.; Tarantino, E. Reuse of treated municipal wastewater for globe artichoke irrigation: Assessment of effects on morpho-quantitative parameters and microbial safety of yield. Sci. Hortic. 2016, 213, 55-65. [CrossRef]

11. Reed, S.C.; Crites, R.W.; Middlebrooks, E.J. Natural Systems for Waste Management and Treatment, 2nd ed.; McGraw-Hill, Inc.: New York, NY, USA, 1995.

12. Wuana, R.A.; Okieimen, F.E. Heavy Metals in Contaminated Soils: A Review of Sources, Chemistry, Risks and Best Available Strategies for Remediation. Int. Sch. Res. Not. 2011, 2011, 402647. [CrossRef]

13. Fatta-Kassinos, D.; Kalavrouziotis, I.K.; Koukoulakis, P.H.; Vasquez, M.I. The risks associated with wastewater reuse and xenobiotics in the agroecological environment. Sci. Total Environ. 2011, 409, 3555-3563. [CrossRef] [PubMed]

14. Aydin, M.E.; Aydin, S.; Beduk, F.; Tor, A.; Tekinay, A.; Kolb, M.; Bahadir, M. Effects of long-term irrigation with untreated municipal wastewater on soil properties and crop quality. Environ. Sci. Pollut. Res. 2015, 22, 19203-19212. [CrossRef] [PubMed]

15. Mapanda, F.; Mangwayana, E.N.; Nyamangara, J.; Giller, K.E. The effect of long-term irrigation using wastewater on heavy metal contents of soils under vegetables in Harare, Zimbabwe. Agric. Ecosyst. Environ. 2005, 107, 151-165. [CrossRef]

16. Alobaidy, A.H.M.J.; Al-Sameraiy, M.A.; Kadhem, A.J.; Majeed, A.A. Evaluation of treated municipal wastewater quality for irrigation. J. Environ. Prot. 2010, 1, 216-225. [CrossRef]

17. Qadir, M.; Mateo-Sagasta, J.; Jiménez, B.; Siebe, C.; Siemens, J.; Hanjra, M.A. Environmental Risks and Cost-Effective Risk Management in Wastewater Use Systems. In Wastewater; Springer: Dordrecht, The Netherlands, 2015; pp. 55-72. 
18. Kim, H.K.; Jang, T.I.; Kim, S.M.; Park, S.W. Impact of domestic wastewater irrigation on heavy metal contamination in soil and vegetables. Environ. Earth Sci. 2015, 73, 2377-2383. [CrossRef]

19. Disciglio, G.; Gatta, G.; Libutti, A.; Gagliardi, A.; Carlucci, A.; Lops, F.; Tarantino, A. Effects of irrigation with treated agro-industrial wastewater on soil chemical characteristics and fungal populations during processing tomato crop cycle. J. Soil Sci. Plant Nutr. 2015, 15, 765-780. [CrossRef]

20. Rahman, S.H.; Khanam, D.; Adyel, T.M.; Islam, M.S.; Ahsan, M.A.; Akbor, M.A. Assessment of heavy metal contamination of agricultural soil around Dhaka Export Processing Zone (DEPZ), Bangladesh: Implication of seasonal variation and indices. Appl. Sci. 2012, 2, 584-601. [CrossRef]

21. Brevik, E.C.; Sauer, T.J. The past, present, and future of soils and human health studies. Soil 2015, 1, 35-46. [CrossRef]

22. Simmons, R.W.; Qadir, M.; Drechsel, P. Farm-based measures for reducing human and environmental health risks from chemical constituents in wastewater. In Wastewater Irrigation and Health: Assessing and Mitigating Risks in Low-Income Countries; Drechsel, P., Scott, C.A., Raschid-Sally, L., Redwood, M., Bahri, A., Eds.; Earthscan-International Development Research Centre (IDRC) - International Water Management Institute (IWMI): New Delhi, India, 2010; pp. 209-238.

23. Pulido, M.V.; Font, R.; Obregón-Cano, S.; Moreno-Rojas, R.; López, M.Á.A.; Anter, J.; Muñoz-Serrano, A.; De Haro Bailón, A.; Alonso-Moraga, A.; Del Río-Celestino, M. Cytotoxic and genotoxic effects of metal(oid)s bioactivated in rocket leaves (Eruca vesicaria subsp. sativa Miller). Chemosphere 2013, 93, 2554-2561. [CrossRef] [PubMed]

24. Gupta, N.; Khan, D.K.; Santra, S.C. Determination of public health hazard potential of wastewater reuse in crop production. World Rev. Sci. Technol. Sustain. Dev. 2010, 7, 328-340. [CrossRef]

25. Wang, X.; Zang, S. Distribution characteristics and ecological risk assessment of toxic heavy metals and metalloid in surface water of lakes in Daqing Heilongjiang Province, China. Ecotoxicology 2014, 23, 609-617. [CrossRef] [PubMed]

26. Rattan, R.K.; Datta, S.P.; Chhonkar, P.K.; Suribabu, K.; Singh, A.K. Long-term impact of irrigation with sewage effluents on heavy metal content in soils, crops and groundwater-A case study. Agric. Ecosyst. Environ. 2005, 109, 310-322. [CrossRef]

27. Abdu, N.; Abdulkadir, A.; Agbenin, J.O.; Buerkert, A. Vertical distribution of heavy metals in wastewater-irrigated vegetable garden soils of three West African cities. Nutr. Cycl. Agroecosyst. 2011, 89, 387-397. [CrossRef]

28. Trujillo-González, J.M.; Torres-Mora, M.A.; Keesstra, S.; Brevik, E.C.; Jiménez-Ballesta, R. Heavy metal accumulation related to population density in road dust samples taken from urban sites under different land uses. Sci. Total Environ. 2016, 553, 636-642. [CrossRef] [PubMed]

29. Guénon, R.; Gros, R. Soil microbial functions after forest fires affected by compost quality. Land Degrad. Dev. 2016, 27, 1391-1402. [CrossRef]

30. Paz-Ferreiro, J.; Lu, H.; Fu, S.; Méndez, A.; Gascó, G. Use of phytoremediation and biochar to remediate heavy metal polluted soils: A review. Solid Earth 2014, 5, 65-75. [CrossRef]

31. Mahmoud, E.; Abd, E.-K.N. Heavy metal immobilization in contaminated soils using phosphogypsum and rice straw compost. Land Degrad. Dev. 2015, 26, 819-824. [CrossRef]

32. Gronwald, M.; Don, A.; Tiemeyer, B.; Helfrich, M. Effects of fresh and aged chars from pyrolysis and hydrothermal carbonization on nutrient sorption in agricultural soils. Soil 2015, 1, 475-489. [CrossRef]

33. FAO-ISRIC-ISSS. World Reference Base for Soil Resources; A Framework for International Classification, Correlation and Communication; World Soil Resources Reports 103; Food and Agriculture Organization: Rome, Italy, 2006; p. 132.

34. Blum, W. Soil Protection Concept of the Council of Europe and Integrated Soil Research. In Integrated Soil and Sediment Research: A basis for Proper Protection, Soil and Environment; Eijsackers, H.J.P., Hamer, T., Eds.; Kluwer Academic: Dordrecht, The Netherlands, 1993.

35. Koch, A.; McBratney, A.; Adams, M.; Field, D.; Hill, R.; Crawford, J.; Zimmermann, M. Soil security: Solving the global soil crisis. Glob. Policy 2013, 4, 434-441. [CrossRef]

36. Pla, I. Advances in soil conservation research: Challenges for the future. Span. J. Soil Sci. 2014, 4, $265-282$. [CrossRef]

37. Barbero-Sierra, C.; Marques, M.J.; Ruiz-Pérez, M.; Escadafal, R.; Exbrayat, W. How is desertification research addressed in Spain? Land versus soil approaches. Land Degrad. Dev. 2015, 26, 423-432. [CrossRef] 
38. Xie, L.W.; Zhong, J.; Chen, F.F.; Cao, F.X.; Li, J.J.; Wu, L.C. Evaluation of soil fertility in the succession of karst rocky desertification using principal component analysis. Solid Earth 2015, 6, 515. [CrossRef]

39. Arora, M.; Kiran, B.; Rani, S.; Rani, A.; Kaur, B.; Mittal, N. Heavy metal accumulation in vegetables irrigated with water from different sources. Food Chem. 2008, 111, 811-815. [CrossRef]

40. Nyamangara, J.; Mzezewa, J. The effect of long-term sewage sludge application on $\mathrm{Zn}, \mathrm{Cu}, \mathrm{Ni}$ and $\mathrm{Pb}$ levels in a clay loam soil under pasture grass in Zimbabwe. Agric. Ecosyst. Environ. 1999, 73, 199-204. [CrossRef]

41. Cao, Z.H.; Hu, Z.Y. Copper contamination in paddy soils irrigated with wastewater. Chemosphere 2000, 41, 3-6. [CrossRef]

42. Singh, K.P.; Mohan, D.; Sinha, S.; Dalwani, R. Impact assessment of treated/untreated wastewater toxicants discharged by sewage treatment plants on health, agricultural, and environmental quality in the wastewater disposal area. Chemosphere 2004, 55, 227-255. [CrossRef] [PubMed]

43. Instituto Geográfico Agustín Codazzi-IGAC. Estudio General de Suelos y Zonificación de Tierras; Departamento de Meta: Bogotá, Colombia, 2004.

44. Micó, C.; Recatalá, L.; Peris, M.; Sánchez, J. Assessing heavy metal sources in agricultural soils of an European Mediterranean area by multivariate analysis. Chemosphere 2006, 65, 863-872. [CrossRef] [PubMed]

45. Instituto Geográfico Agustín Codazzi (IGAC). Métodos Analíticos del Laboratorio de Suelos, 6th ed.; IGAC: Bogotá, Colombia, 2006; p. 648.

46. UN Water. Tackling a Global Crisis: International Year of Sanitation 2008. Available online: http://esa.un. org/iys/docs/IYS_flagship_web_small.pdf (accessed on 15 April 2015).

47. Chaggu, E.; Mashauri, D.; Buuren, J.V.; Sanders, W.; Lettinga, G. Excreta Disposal in Dar-es-Salaam. Environ. Manag. 2002, 30, 609-620. [CrossRef] [PubMed]

48. Ecopetrol. Caracterización Fisicoquímica, Hidrobiológica y Ecotoxicológica Aguas Residuales Industriales Estación de Recolección Apiay (era) y Cuerpo de Agua Receptor de su Vertimiento (Río Ocoa); Informe Técnico; Ecopetrol: Bogotá, Colombia, 2014.

49. Krook, J.; Svensson, N.; Eklund, M. Landfill mining: A critical review of two decades of research. Waste Manag. 2012, 32, 513-520. [CrossRef] [PubMed]

50. Abu-Daabes, M.; Qdais, H. A.; Alsyouri, H. Assessment of Heavy Metals and Organics in Municipal Solid Waste Leachates from Landfills with Different Ages in Jordan. J. Environ. Prot. 2013, 4, 344-352. [CrossRef]

51. Bos, R.; Carr, R.; Keraita, B. Assessing and mitigating wastewater related health risks in low-income countries: An introduction. In Wastewater Irrigation and Health: Assessing and Mitigating Risks in Low-Income Countries; Drechsel, P., Scott, C.A., Raschid-Sally, L., Redwood, M., Bahri, A., Eds.; Earthscan-International Development Research Centre (IDRC)—International Water Management Institute (IWMI): New Delhi, India, 2010; pp. 29-47.

52. World Health Organization. Wastewater Use in Agriculture. In Guidelines for the Safe Use of Wastewater, Excreta and Grey Water; World Health Organization: Geneva, Switzerland, 2006; Volume 2.

53. Brindha, K.; Elango, L. Soil and groundwater quality with reference to nitrate in a semiarid agricultural region. Arab. J. Geosci. 2014, 7, 4683-4695. [CrossRef]

54. US Department of Agriculture. Soil Survey Staff Soil Survey Manual; Handbook 18; US Government Printing Office: Washington, DC, USA, 1951.

55. McKeague, J.A.; Fox, C.A.; Stone, J.A.; Protz, R. Effects of cropping system on structure of Brookston clay loam in long-term experimental plots at Woodslee, Ontario. Can. J. Soil Sci. 1987, 67, 571-584. [CrossRef]

56. Reynolds, W.D.; Drury, C.F.; Yang, X.M.; Tan, C.S.; Yang, J.Y. Impacts of 48 years of consistent cropping, fertilization and land management on the physical quality of a clay loam soil. Can. J. Soil Sci. 2014, 94, 403-419. [CrossRef]

57. Zapata, R. Química de la Acidez del Suelo; Universidad Nacional de Colombia: Bogotá, Colombia, 2004.

58. US Department of Agriculture. Soil Survey Manual. In Soil Survey Division Staff; Handbook 18; Soil Conservation Service; Government Printing Office: Washington, DC, USA, 1993; p. 437.

59. Oo, A.N.; Iwai, C.B.; Saenjan, P. Soil properties and maize growth in saline and nonsaline soils using cassava-industrial waste compost and vermicompost with or without earthworms. Land Degrad. Dev. 2015, 26, 300-310. [CrossRef]

60. Sommer, M. Influence of soil pattern on matter transportation in and from terrestrial biogeosystems-A new concept for landscape pedology. Geoderma 2006, 133, 107-123. [CrossRef] 
61. Sinegani, A.A.S.; Mahboobi, A.A.; Nazarizadeh, F. The effect of agricultural practices on the spatial variability of arbuscular mycorrhiza spores. Turk. J. Biol. 2005, 29, 149-153.

62. Elliott, H.A.; Jaiswal, D. Phosphorus Management for Sustainable Agricultural Irrigation of Reclaimed Water. J. Environ. Eng. 2011, 138, 367-374. [CrossRef]

63. Kabata, A.; Mukherjee, A. Trace Elements from Soil to Human; Springer: New York, NY, USA, 2007.

64. Klay, S.; Charef, A.; Ayed, L.; Houman, B.; Rezgui, F. Effect of irrigation with treated wastewater on geochemical properties (saltiness, C, N and heavy metals) of isohumic soils (Zaouit Sousse perimeter, Oriental Tunisia). Desalination 2010, 253, 180-187. [CrossRef]

65. Rincón, C.A.; Caicedo, G.S. Monitoreo de las condiciones de los suelos establecidos con la asociación maíz/pastos para la recuperación praderas degradadas en el piedemonte llanero. In Memorias, Proceedings of the XV Congreso Colombiano de la Ciencia del Suelo, "El suelo: soporte de la biodiversidad y la producción en los agroecosistemas tropicales", Pereira, Colombia, 27-19 October 2010; Sociedad Colombiana de la Ciencia del Suelo, Comité Regional Eje Cafetero (CD-ROM), 2010.

66. Jamioy-Orozco, D.; Menjivar-Flores, J.; Rubiano-Sanabria, Y. Indicadores químicos de calidad de suelos en sistemas productivos del Piedemonte de los Llanos Orientales de Colombia. Acta Agron. 2015, 64, 302-307. [CrossRef]

67. Mahecha-Pulido, J.D.; Trujillo-González, J.M.; Torres-Mora, M.A. Contenido de Metales Pesados en Suelos Agrícolas de la Región del Ariari; Departamento del Meta: Orinoquia, Colombia, 2015; pp. 118-122.

68. Cerdà, A. Relationships between climate and soil hydrological and erosional characteristics along climatic gradients in Mediterranean limestone areas. Geomorphology 1998, 25, 123-134. [CrossRef]

69. Yang, S.; Ou, G.; Liu, J.; Wang, J.; Lu, G.; Ji, X. Seasonal variations in physical properties of shallow soils on the slope of Mt. Gongga, China. Arab. J. Geosci. 2015, 8, 1261-1271. [CrossRef]

70. Azouzi, R.; Charef, A.; Khadhar, S.; Shabou, N.; Boughanmi, H.; Hjiri, B.; Hajjaj, S. Effect of long-term irrigation with treated wastewater of three soil types on their bulk densities, chemical properties and PAHs content in semi-arid climate. Arab. J. Geosci. 2016, 9, 1-13. [CrossRef]

71. Cerdà, A. Effect of climate on surface flow along a climatological gradient in Israel: A field rainfall simulation approach. J. Arid. Environ. 1998, 38, 145-159. [CrossRef]

72. Bockheim, J.G.; Gennadiyevm, A.N.; Hartemink, A.E.; Brevik, E.C. Soil-forming factors and Soil Taxonomy. Geoderma 2014, 226, 231-237. [CrossRef]

73. Campos, A.C.; Etchevers, J.B.; Oleschko, K.L.; Hidalgo, C.M. Soil microbial biomass and nitrogen mineralization rates along an altitudinal gradient on the cofre de perote volcano (Mexico): The importance of landscape position and land use. Land Degrad. Dev. 2014, 25, 581-593. [CrossRef] 